ANNA TOBOLSKA

Uniwersytet Adama Mickiewicza, Poznań

\title{
Procesy koncentracji gospodarczej dużych przedsiębiorstw przemysłowych Poznania
}

Celem pracy jest przedstawienie przebiegu procesów koncentracji gospodarczej na podstawie zmian organizacyjnych i własnościowych zachodzących w dużych przedsiębiorstwach przemysłowych Poznania. Procesy koncentracji gospodarczej są jednym z najistotniejszych współczesnych zjawisk ekonomicznych. Polegają one na skupianiu w jednym organizmie gospodarczym coraz większych zasobów używanych do prowadzenia działalności gospodarczej na coraz większą skalę. Wynikiem tych procesów jest funkcjonowanie wieloczłonowych podmiotów gospodarczych, a więc takich, które składają się z podporządkowanych jednostek organizacyjno-gospodarczych o zróżnicowanym statusie prawnym i ekonomicznym. Procesy koncentracji gospodarczej, utożsamiane w swoim aspekcie zewnętrznym z procesami integracji, pokazują mechanizm organizacyjny powstawania sieci przemysłowych tworzonych przez wielonarodowe koncerny funkcjonujące w skali globalnej.

Wraz z procesami koncentracji gospodarczej zachodzącymi w dużych przedsiębiorstwach przemysłowych i ich zmianami organizacyjnymi następują zmiany przestrzenne działalności tych przedsiębiorstw i ich oddziałów, funkcjonujących najczęściej w formie mniej lub bardziej zależnych spółek.

Na gruncie nauk z zakresu organizacji i zarządzania wyróżnia się dwa rodzaje procesów koncentracji gospodarczej (Koziński 1996, s. 123-128): 1) koncentrację zewnętrzną, nazywaną też koncentracją organizacyjną i 2) koncentrację wewnętrzną.

1) Proces koncentracji zewnętrznej lub organizacyjnej utożsamiany jest z procesami integracji. Może prowadzić do łączenia dotychczas niezależnych od siebie podmiotów gospodarczych, w wyniku czego powstaje jeden wspólny organizm gospodarczy, składający się z wielu podmiotów o różnym stopniu spójności organizacyjnej. Tak powstały nowy podmiot gospodarczy charakteryzuje się wielkim rozmiarem zarówno zasobów, jak i zdolności produkcyjnych, dużą skalą przestrzenną działalności i dużym udziałem w rynku.

W zależności od stopnia spójności organizacyjnej można wyróżnić wiele form integracji i współdziałania podmiotów gospodarczych (por. ryc. 1). Pierwszą formą jest integracja kooperacyjna, która nie pozbawia podmiotów uczestniczących w tego rodzaju integracji samodzielności prawnej ani gospodarczej, a do której zaliczyć można m.in. takie formy powiązań między przedsiębiorstwami, jak np. alianse strategiczne. Proces koncentracji organizacyjnej może doprowadzić w dłuższym czasie do całkowitego scalenia organizacyjnogospodarczego poszczególnych jednostek-uczestników integracji i do powstania jednego, dużego przedsiębiorstwa. Podmioty uczestniczące tracą wówczas swą dotychczasową sa- 
modzielność prawną i ekonomiczną, stają się wewnętrznymi jednostkami produkcyjnotechnicznymi, podporządkowanymi jednolitemu kierownictwu.

2) Drugim rodzajem koncentracji jest koncentracja wewnętrzna, polegająca na wzroście wielkości przedsiębiorstwa jednozakładowego, na wzroście skali jego działalności, również przestrzennej i powiększeniu jego udziału w rynku. W wyniku tego wzrostu i po przekroczeniu granicy sterowności zarządzania tak wielkim przedsiębiorstwem, następuje w jego strukturze wyodrębnienie poszczególnych wewnętrznych jednostek organizacyjnych. W miarę nadawania im coraz większej samodzielności prawnej i ekonomicznej maleje spójność struktury organizacyjnej. Proces ten nazywam autonomizacją jednostek organizacyjnych, jednak na gruncie nauk z zakresu organizacji i zarządzania określa się go mianem dywizjonalizacji (np. Wudarzewski 1996, s. 73); można też spotkać się z innymi terminami na oznaczenie tego procesu, np. fragmentacja (Domański 1992, s. 66) czy atomizacja (Nizard 1991, tłum. pol. 1998, s. 143). Prowadzi on w rezultacie do utworzenia przedsiębiorstwa wieloczłonowego, a w dalszej kolejności do powstania ugrupowania gospodarczego o silnie zatomizowanej (,zdywizjonalizowanej”) strukturze organizacyjnej.

Proces koncentracji wewnętrznej przebiega więc w odwrotnym kierunku do procesu koncentracji zewnętrznej i następuje wraz ze zmniejszaniem się spoistości organizacyjnej przedsiębiorstwa, prowadząc do powstania podmiotów wieloczłonowych. Systematyzację form koncentracji gospodarczych, w zależności od stopnia zwartości organizacyjnej przedsiębiorstw oraz stopnia autonomizacji jednostek organizacyjnych, przedstawia ryc. 1.

PROCES KONCENTRACJI WEWNĘTRZNEJ
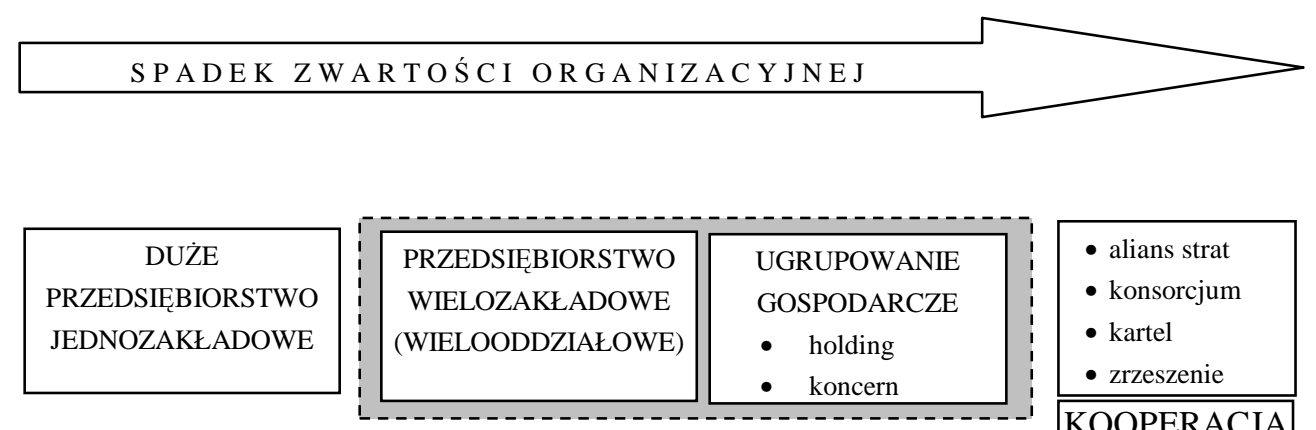

\begin{tabular}{l} 
- alians strat \\
- konsorcjum \\
- kartel \\
- zrzeszenie \\
\hline KOOPERACJA \\
\hline
\end{tabular}

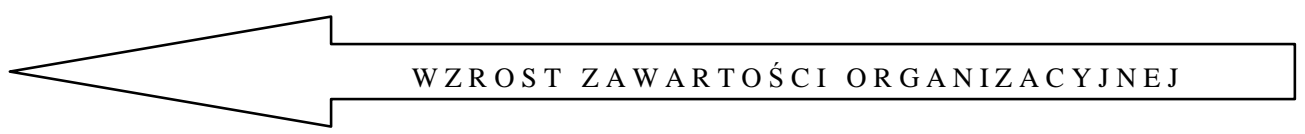

PROCES KONCENTRACJI ZEWNĘTRZNEJ (INTEGRACJI)

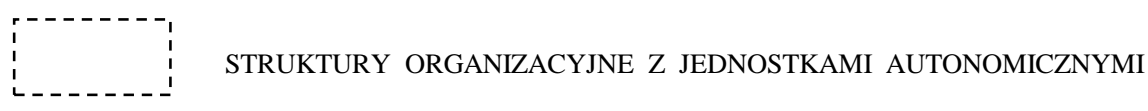

Ryc. 1. Formy koncentracji gospodarczej według stopnia zwartości organizacyjnej oraz autonomizacji struktur organizacyjnych

Źródło: opracowanie własne na podst. Koziński 1996, s. 123-127 
Przykłady procesu koncentracji gospodarczej - zarówno zewnętrznej, jak i wewnętrznej - można znaleźć również analizując przebieg zmian organizacyjnych zachodzących w dużych przedsiębiorstw przemysłowych Poznania. Badaniami objęto 14 dużych przedsiębiorstw przemysłowych, tj. zatrudniających powyżej 500 pracowników. Przedstawione wyniki odzwierciedlają zmiany zachodzące w tych przedsiębiorstwach w latach 1990-1998, a więc w okresie ich dostosowywania się do warunków gospodarki rynkowej, w czasie ich restrukturyzacji i prywatyzacji.

\section{PROCESY KONCENTRACJI WEWNĘTRZNEJ I AUTONOMIZACJA JEDNOSTEK ORGANIZACYJNYCH}

Procesy koncentracji wewnętrznej w dużych przedsiębiorstwach przemysłowych Poznania przebiegają wraz z ewolucją ich struktur organizacyjnych na drodze autonomizacji wewnętrznych jednostek organizacyjnych. Następuje bowiem wydzielanie się ze struktur organizacyjnych poszczególnych oddziałów i wewnętrznych jednostek organizacyjnych i ich ekonomiczne i prawne usamodzielnianie działalności. Wynikiem autonomizacji jednostek organizacyjnych jest również przestrzenne rozszerzenie działalności tych przedsiębiorstw, na skutek wzrostu powiązań zewnętrznych, a także lokalizacji nowych jednostek organizacyjnych poza dotychczasową siedzibą przedsiębiorstwa.

Dla zilustrowania przebiegu omawianych procesów przedstawione zostaną zmiany w organizacji przedsiębiorstwa „LECH” Browary Wielkopolski S.A. (a od 1999 roku Kompania Piwowarska S.A.).

Na początku lat 90. XX wieku przedsiębiorstwo „LECH” BW S.A., ówczesne Zakłady Piwowarskie, było przedsiębiorstwem wielozakładowym, składającym się z 11 podległych jednostek organizacyjnych bez osobowości prawnej. Struktura organizacyjna tego przedsiębiorstwa miała charakter regionalny, co oznacza, że poszczególne jednostki organizacyjne w tej strukturze zostały ukształtowane zgodnie z kryterium regionalnym (omówienie kryteriów wydzielania podstawowych struktur organizacyjnych przedstawia np. Wudarzewski 1996, s. 64-89). W przypadku „LECHA” oznacza to, że ich działalność zlokalizowana była w różnych jednostkach terytorialnych i skierowana była na potrzeby różnych terytorialnie rynków zbytu (ryc. 2).

W strukturze poznańskich Zakładów Piwowarskich do roku 1992 obok centralnych komórek organizacyjnych, wyodrębnionych według kryterium funkcjonalnego (takich jak: dział służb pracowniczych, dział organizacji i kontroli, służba kontroli jakości, pełnomocnik do spraw inwestycji, radca prawny oraz trzy rozbudowane piony zastępców dyrektora naczelnego: do spraw technicznych, do spraw handlowo-surowcowych, do spraw ekonomiczno-finansowych), zasadniczymi częściami przedsiębiorstwa były regionalne jednostki organizacyjne. Były to browary zlokalizowane w Poznaniu, Ostrowie, Krotoszynie, Bojanowie, Miłosławiu, Grodzisku, dwie słodownie w Poznaniu, słodownia w Stawiszynie, wytwórnie wód gazowanych w Śmiglu oraz w Poznaniu, wytwórnia Pepsi-Coli. Te jednostki regionalne w strukturze przedsiębiorstwa podlegały bezpośrednio dyrektorowi naczelnemu. 


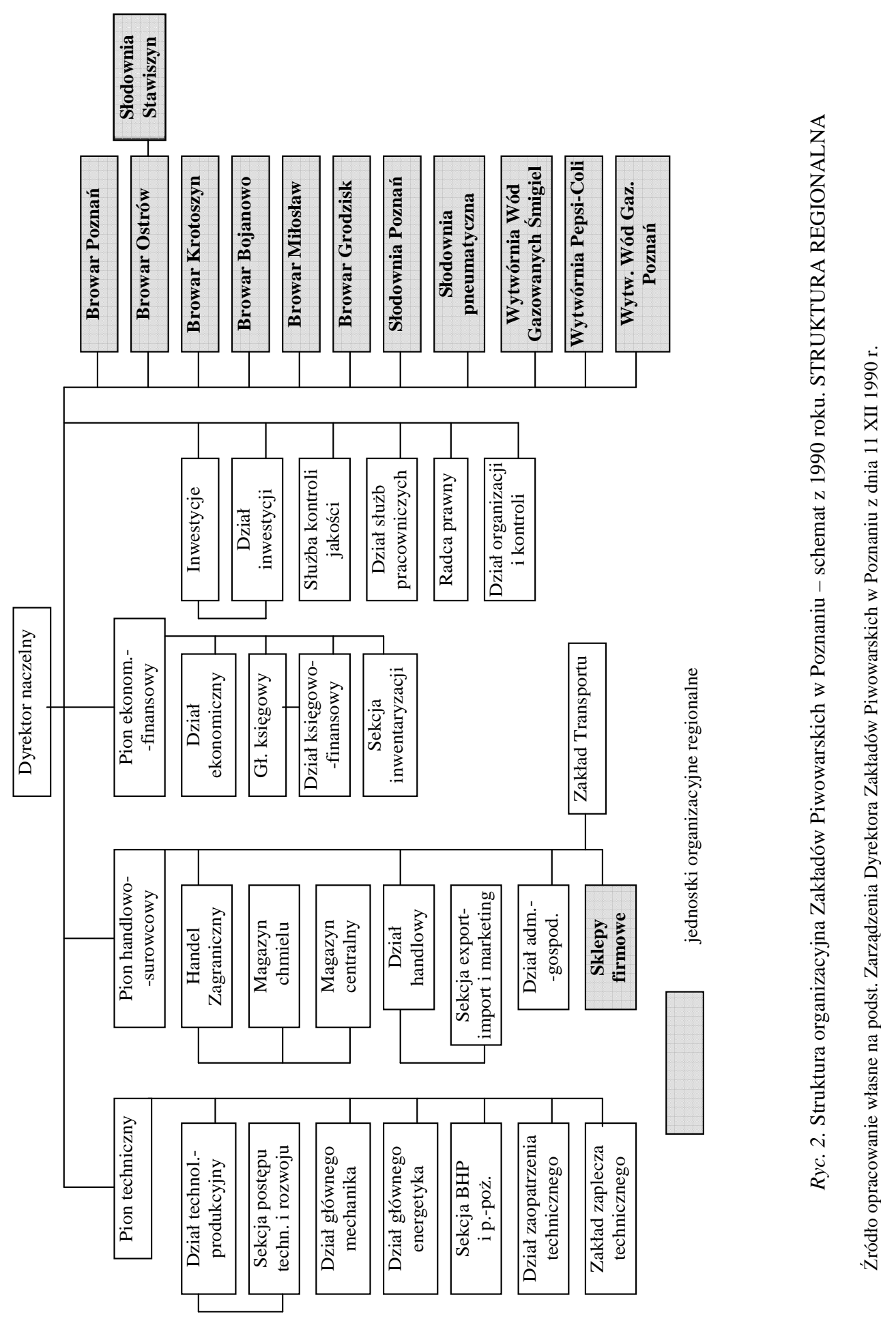


Zmiany organizacyjne w „LECHU” rozpoczęto wraz ze zmianą statusu prawnego przedsiębiorstwa i przekształceniem go w 1992 roku w spółkę akcyjną, a następnie w 1993 roku po sprzedaży większościowego pakietu akcji inwestorowi strategicznemu, jakim była spółka J. Kulczyka Euro Agro Centrum. Kolejne regionalne jednostki organizacyjne uzyskiwały samodzielność i odłączały się od zakładu macierzystego, bądź przekształcone zostały w spółki ze znacznym udziałem „LECHA”. Już w 1992 roku Wytwórnię Wód Gazowanych w Śmiglu przekształcono w spółkę ze 100\% udziałem LECHA, a w 1994 roku z browaru w Bojanowie utworzono spółkę z o.o. wraz ze spadkobiercami, w której „LECH” miał jednak większościowy pakiet akcji $(64,7 \%)$. W 1995 roku oddano byłym właścicielom browar w Miłosławiu na mocy decyzji Ministra Rolnictwa i Gospodarki Żywnościowej. W tym samym roku sprzedano browar w Grodzisku oraz słodownię w Stawiszynie, w której ze względu na nieopłacalność zaprzestano nawet produkcji (pracowała jedynie na potrzeby browaru ostrowskiego). Browar w Krotoszynie oraz wytwórnię Pepsi-Coli wraz z oddziałem przy ul. Półwiejskiej w Poznaniu przekształcono w spółki z o.o. („LECH” Browar Krotoszyn Sp. z o.o. oraz „LECH” Napoje Sp. z o.o.), ze 100-procentowym udziałem „LECHA”. Ponadto Zakład Transportu, będący do tej pory integralną częścią przedsiębiorstwa został z niego wydzielony w odrębną spółkę, działającą głównie na zlecenia „LECHA”. Tak więc w przedsiębiorstwie macierzystym zostały 4 zakłady produkcyjne: browar w Poznaniu, słodownia i słodownia pneumatyczna w Poznaniu oraz browar w Ostrowie. Dalsza restrukturyzacja organizacyjna przedsiębiorstwa polegała na utworzeniu w 1994 roku 13 spółek handlowych w różnych regionach kraju, tzw. centrów dystrybucji. Do 1997 roku liczba centrów dystrybucji wraz z hurtowniami patronackimi wzrosła do 34 (ryc. 3).

Dotychczasowa struktura organizacyjna uległa wysmukleniu (tzn. zwiększyła się liczba szczebli zarządzania) i dywersyfikacji. Dotychczasowe działy i piony zarządzania w przedsiębiorstwie zostały zastąpione pięcioma departamentami (marketingu, sprzedaży, finansów, produkcji i techniki oraz rozwoju produkcji), dzielącymi się na działy, sekcje i stanowiska. Ponadto w strukturze zakładu funkcjonują centralne komórki organizacyjne, takie jak dział kadr i szkoleń ze stanowiskiem ds. socjalnych, dział organizacyjno-prawny, dział administracji, sekcja public relation, a także komórka asystentów zarządu i doradców zarządu spółki. Na szczególną uwagę zasługuje rozwój departamentów marketingu i sprzedaży, powstałych na bazie byłego działu handlowego, w którym jeszcze w 1994 roku zatrudnionych było 15 osób, a już w 1996 roku - 150. Tak więc jednostki organizacyjne „LECHA” uległy dość znacznej autonomizacji, przez co przedsiębiorstwo przybrało formę ugrupowania gospodarczego o strukturze koncernowej, składającej się z czterech spółek produkcyjnych („LECH” jest ciągle udziałowcem w browarach w Krotoszynie, Bojanowie oraz w wytwórniach wód gazowanych), 34 centrów dystrybucji o statusie spółek z o.o. oraz samodzielnej spółki transportowej. Poprzez te zmiany organizacyjne zasięg przestrzenny przedsiębiorstwa zwiększył się i objął teren prawie całego kraju (ryc. 3 i 4). 


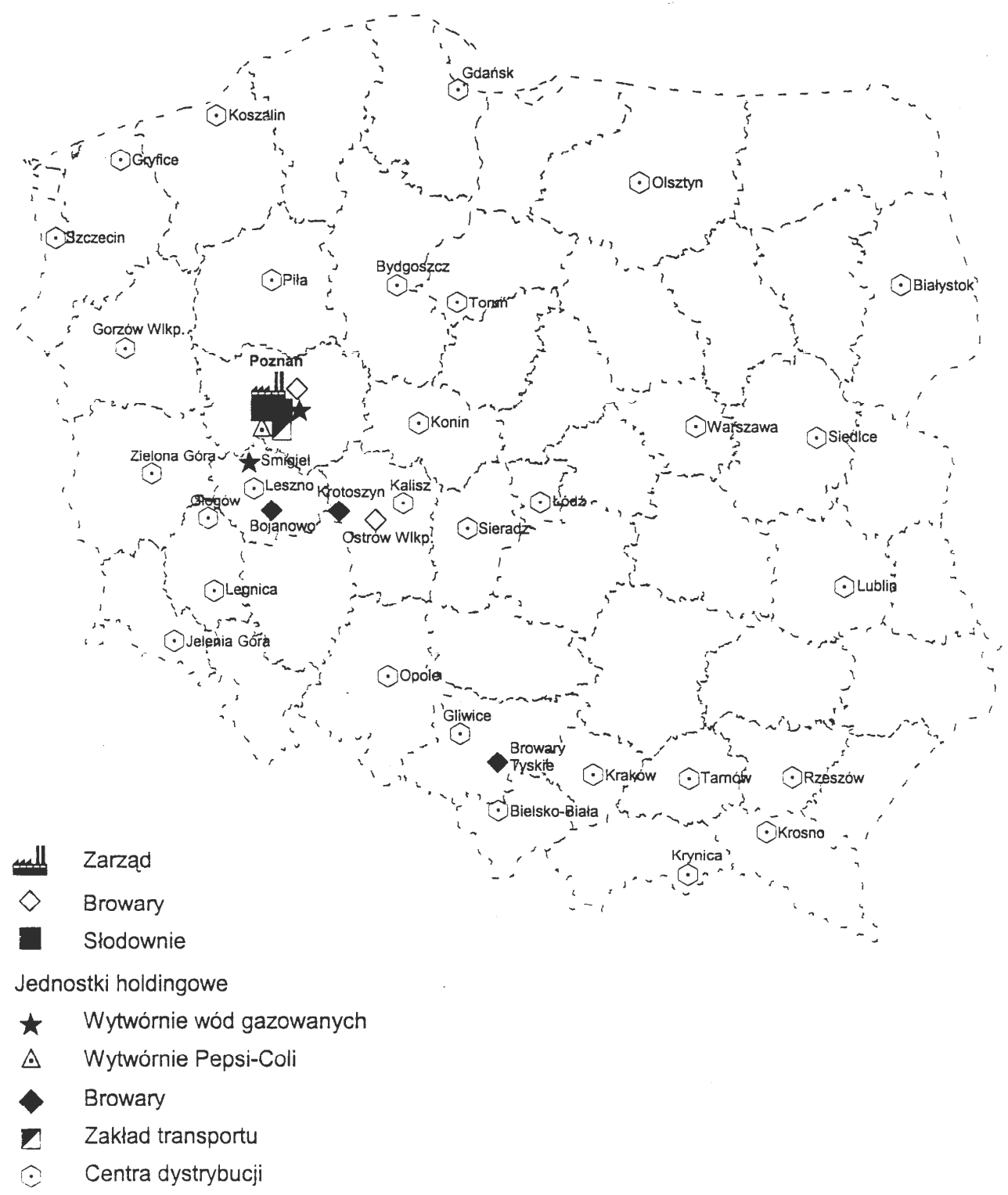

Ryc. 3. Organizacja przestrzenna LECH Browary Wielkopolski S.A. (1996)

Źródło: opracowanie na podstawie danych z przedsiębiorstwa 


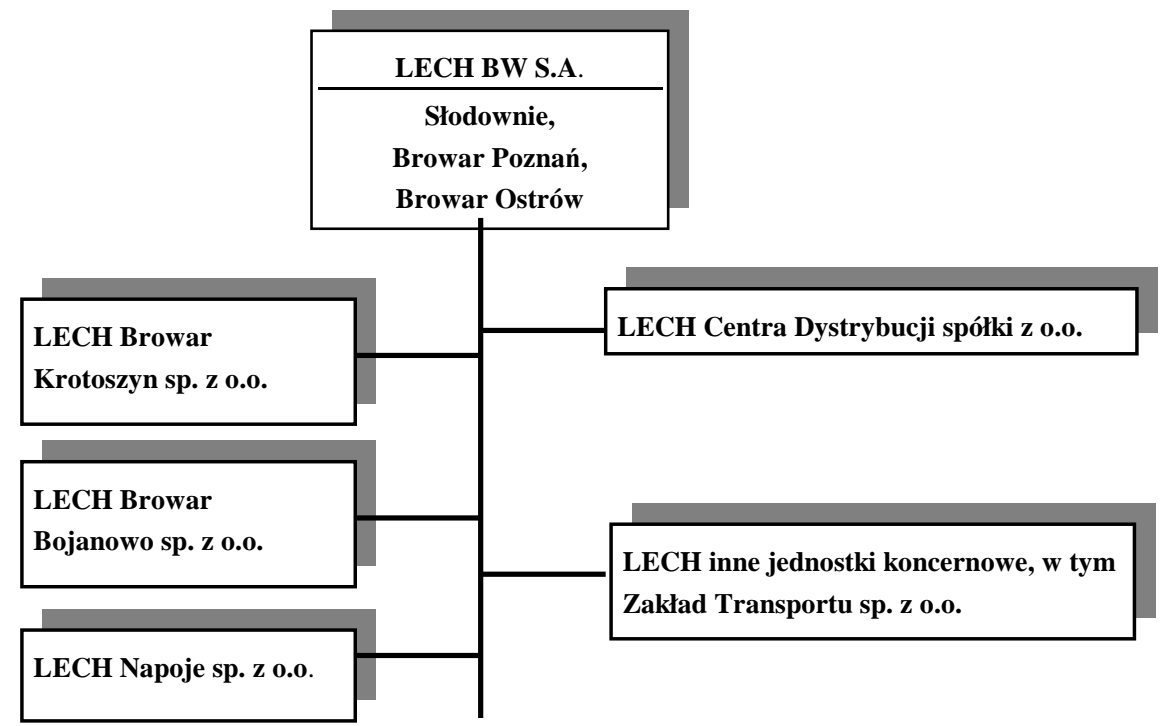

Ryc. 4. Struktura koncernowa LECH Browary Wielkopolski S.A. w 1997 roku

Źródło: opracowanie własne

\section{PROCESY KONCENTRACJI ORGANIZACYJNEJ I WŁĄCZANIE SIĘ PRZEDSIĘBIORSTW W MIĘDZYNARODOWE SIECI UGRUPOWAŃ GOSPODARCZYCH}

Drugim rodzajem koncentracji gospodarczej jest koncentracja zewnętrzna, którą można identyfikować $\mathrm{z}$ integracją organizacyjną kilku samodzielnych firm $\mathrm{w}$ jeden organizm gospodarczy, poddany wspólnemu zarządowi. W analizowanych przypadkach dużych przedsiębiorstw przemysłowych Poznania zaobserwowano ponadto dwa rodzaje koncentracji zewnętrznej (integracji): 1) w drodze opanowania i 2) w drodze konsolidacji (różnice pomiędzy tymi dwoma rodzajami koncentracji przedstawiono na podstawie opracowania J. Kozińskiego (1996, s. 128, ryc. 5).

1) Koncentracja zewnętrzna $w$ drodze opanowania polega na podporządkowaniu sobie przez przedsiębiorstwo (najczęściej silne koncerny międzynarodowe) innych prawnie odrębnych firm, które tracą w różnym stopniu swą samodzielność i wchodzą w skład wieloczłonowego podmiotu gospodarczego jako jego jednostki organizacyjne. Ten rodzaj koncentracji zewnętrznej wystąpił wśród badanych przedsiębiorstw poznańskich w wyniku sprzedaży kontrolnych pakietów akcji niektórych z nich wielonarodowym koncernom. Tym samym nastąpiło włączenie w ich struktury organizacyjne, w formie podporządkowanych jednostek. 

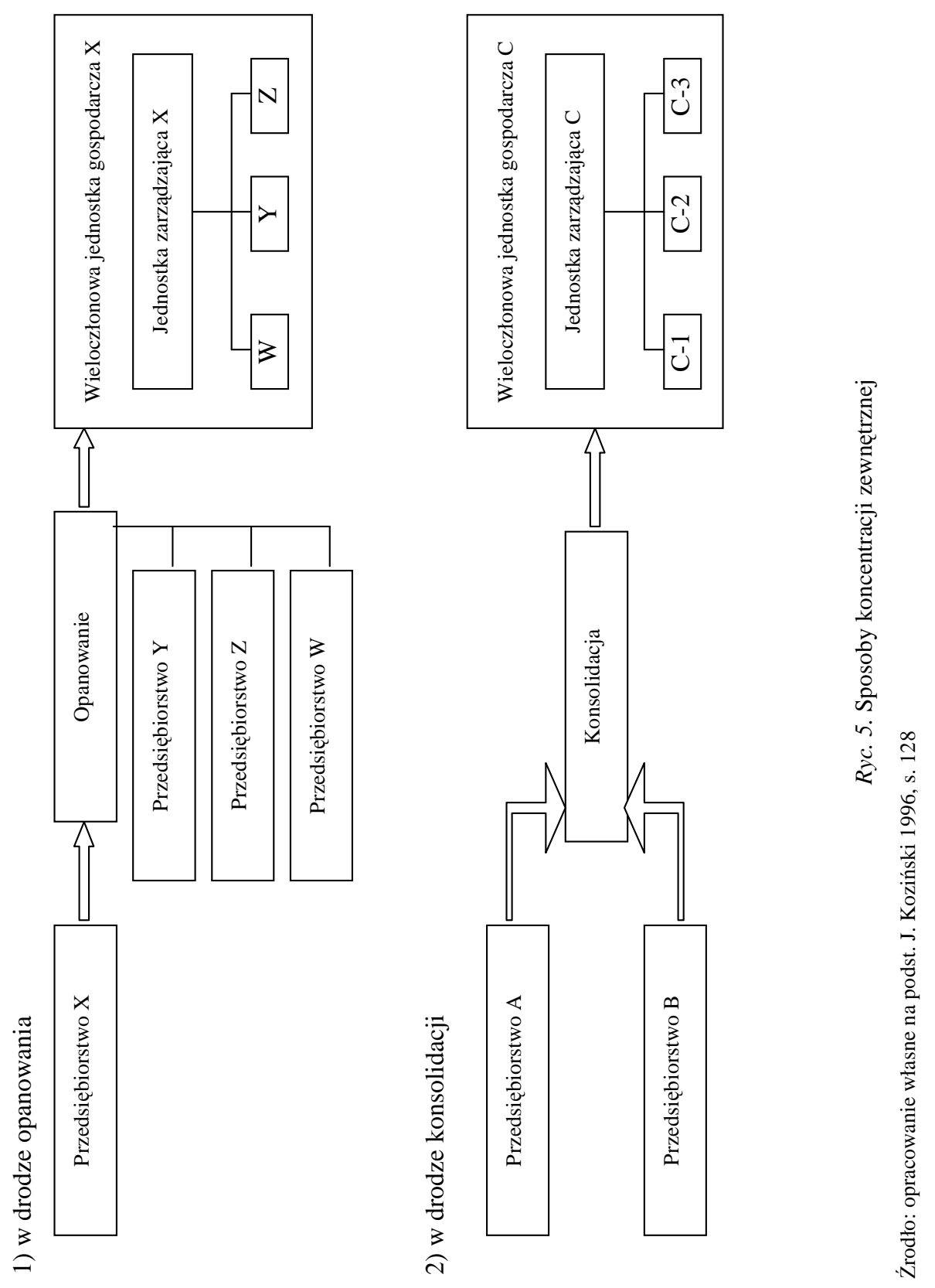
2) Koncentracja zewnętrzna w drodze konsolidacji polega na tym, że dwie samodzielne firmy tworzą dobrowolnie nowy wieloczłonowy podmiot gospodarczy, stając się jego jednostkami organizacyjnymi. Utworzenie wspólnego organizmu gospodarczego ma na celu realizację sformułowanych strategii gospodarczych.

Wśród dużych przedsiębiorstw poznańskich przypadek konsolidacji organizacyjnej wystąpił w momencie fuzji przedsiębiorstwa LECH Browary Wielkopolski S.A. z Browarami Tyskimi (marzec 1999) i utworzeniu wspólnego ugrupowania gospodarczego w formie holdingu - Kompanii Piwowarskiej, ze wspólnym ośrodkiem zarządzającym zlokalizowanym w Poznaniu oraz wspólnymi wewnętrznymi jednostkami organizacyjnymi w postaci wspólnych centrów dystrybucji. Został zrealizowany przy tym cel strategiczny: zwiększenie udziału w rynku piwa w Polsce do $20 \%$.

Przypadki koncentracji zewnętrznej (integracji), której uczestnikami były duże zakłady przemysłowe Poznania przedstawia tabela 1.

Tabela 1. Przykłady koncentracji organizacyjnej (integracji) dużych przedsiębiorstw przemysłowych Poznania

\begin{tabular}{|c|c|}
\hline $\begin{array}{l}\text { Przedsiębiorstwa inicjujące } \\
\text { koncentrację organizacyjną }\end{array}$ & Przedsiębiorstwa - uczestnicy koncentracji organizacyjnej \\
\hline \multicolumn{2}{|l|}{ 1) koncentracja w drodze opanowania } \\
\hline $\begin{array}{l}\text { Corn Product Corporation (CPC) } \\
\text { International Europe Group } \\
\text { - spożywczy koncern amerykański } \\
\text { z siedzibą Grupy Europejskiej } \\
\text { w Brukseli }\end{array}$ & $\begin{array}{l}\text { Zakłady Koncentratów Spożywczych „Amino” S.A. } \\
\text { W } 1992 \text { roku CPC zakupił 80\% akcji tej spółki, a następnie } \\
\text { odkupił od Skarbu Państwa i od pracowników pozostałą ich } \\
\text { część i w } 1996 \text { roku był właścicielem 99,9\% akcji. } \\
\text { CPC,,Amino” sp. z o.o. stało się jedną ze } 116 \text { firm spożyw- } \\
\text { czych należących do koncernu, zlokalizowanych w } 52 \text { kra- } \\
\text { jach świata. W wyniku dalszych procesów integracyjnych } \\
\text { „Amino” zostało przejęte przez koncern „Bestfoods”. }\end{array}$ \\
\hline $\begin{array}{l}\text { Compagne Europeenne } \\
\text { D’Accumulateurs (CEAC) - to } \\
\text { spółka koncernów Fiata (w 63\%) } \\
\text { i Alcatela (w 37\%) z siedzibą } \\
\text { w Paryżu, powiązana kooperacyjnie } \\
\text { z producentami akumulatorów: } \\
\text { SINAC, CFEC-STECO, Fulmen, } \\
\text { Tudor, tworzących najsilniejszą } \\
\text { grupę w produkcji akumulatorów } \\
\text { w Europie }\end{array}$ & $\begin{array}{l}\text { „Centra” S.A. } \\
\text { W } 1994 \text { roku CEAC kupiło 75\% akcji „Centry”, które już } \\
\text { w } 1995 \text { roku zostały z kolei zakupione przez amerykańską } \\
\text { grupę EXIDE, największego producenta akumulatorów na } \\
\text { świecie (ok. 20-procentowy udział w światowej produkcji), } \\
\text { posiadającego ponad } 25 \text { przedsiębiorstw w różnych krajach. }\end{array}$ \\
\hline $\begin{array}{l}\text { Volkswagen AG } \\
\text { Niemiecki koncern z siedzibą } \\
\text { w Wolfsburgu, obecnie po fuzji } \\
\text { z koncernem samochodowym Audi }\end{array}$ & $\begin{array}{l}\text { Fabryka Samochodów Rolniczych „Polmo” i powstała po jej } \\
\text { likwidacji spółka z o.o. „Tarpan”. } \\
\text { W } 1993 \text { roku utworzono spółkę joint venture „Volkswagen } \\
\text { Poznań”, w której VW miał 25,5\% udziałów. Po likwidacji } \\
\text { „Tarpan” sp. z o.o. od } 1997 \text { roku VW jest jedynym właści- } \\
\text { cielem spółki. }\end{array}$ \\
\hline $\begin{array}{l}\text { Nestle } \\
\text { Szwajcarski koncern, z siedzibą } \\
\text { w Vevey, jeden z największych } \\
\text { producentów żywności na świecie }\end{array}$ & $\begin{array}{l}\text { Zakłady Przemysłu Cukierniczego „Goplana” S.A. } \\
\text { W } 1994 \text { roku Nestle objęło 47\% akcji w „Goplanie” } \\
\text { w zamian za inwestycje o wartości 35,9 mln \$, a dalsze inwe- } \\
\text { stycje podniosły ten udział do 51,7\% w } 1996 \text { roku i 76,97\% } \\
\text { w } 1997 \text { roku. Od } 1996 \text { roku „Goplana” została jedną }\end{array}$ \\
\hline
\end{tabular}




\begin{tabular}{|c|c|}
\hline & $\begin{array}{l}\text { z czterech firm, które utworzyły grupę Nestle Polska Holding } \\
\text { sp. z o.o. Koncern Nestle posiada } 489 \text { zakładów na } 5 \text { konty- } \\
\text { nentach }\end{array}$ \\
\hline $\begin{array}{l}\text { AB SKF } \\
\text { Szwedzki koncern z siedzibą w Gö- } \\
\text { teborgu, produkujący łożyska tocz- } \\
\text { ne i posiadający 20-procentowy } \\
\text { udział w światowym rynku tych } \\
\text { wyrobów } \\
\end{array}$ & $\begin{array}{l}\text { Fabryka Łożysk Tocznych S.A. } \\
\text { W } 1995 \text { roku szwedzki koncern zakupił } 79 \% \text { akcji fabryki, } \\
\text { a w } 1997 \text { roku, po przekazaniu przez Skarb Państwa ostat- } \\
\text { niego } 1 \text { procenta akcji, był już właścicielem } 99 \% \text {. Koncern } \\
\text { SKF posiada } 80 \text { zakładów produkujących łożyska na całym } \\
\text { świecie. }\end{array}$ \\
\hline $\begin{array}{l}\text { Beiersdorf AG } \\
\text { Niemiecki koncern kosmetyczno- } \\
\text { chemiczny }\end{array}$ & $\begin{array}{l}\text { Fabryka Kosmetyków „Pollena-Lechia” S.A. } \\
\text { W } 1997 \text { roku niemiecki koncern zakupił nową emisję akcji } \\
\text { serii B Polleny-Lechii od VIII NFI Octava, łącznie 50\%. } \\
\text { Zakup Polleny-Lechii jest elementem strategii koncernu, } \\
\text { zmierzającego do przejęcia wszystkich fabryk produkujących } \\
\text { wyroby pod marką Nivea. Powstała spółka Beiersdorf - Le- } \\
\text { chia S.A. jest jedną z } 14 \text { (zlokalizowanych w różnych kra- } \\
\text { jach) należących do koncernu. }\end{array}$ \\
\hline $\begin{array}{l}\text { Reemtsma Zigarettenfabriken } \\
\text { GmbH } \\
\text { Niemiecki koncern tytoniowy z sie- } \\
\text { dzibą w Hamburgu, należy do grupy } \\
\text { Thibo AG }\end{array}$ & $\begin{array}{l}\text { Wytwórnia Wyrobów Tytoniowych S.A. } \\
\text { W } 1996 \text { kontrolny pakiet akcji WWT 76,2\% zakupiła } \\
\text { Reemtsma, a w kolejnych latach wykupiła dalsze 20\% udzia- } \\
\text { łów pracowniczych (Skarb Państwa posiada jeszcze ponad } \\
3 \% \text { akcji). Koncern ma } 10 \text { fabryk papierosów, m.in. w Sło- } \\
\text { wenii, na Węgrzech, Słowacji, Ukrainie, w Kirgistanie } \\
\text { i Kazachstanie. }\end{array}$ \\
\hline $\begin{array}{l}\text { Glaxo Wellcome } \\
\text { Brytyjski koncern farmaceutyczny }\end{array}$ & $\begin{array}{l}\text { Poznańskie Zakłady Farmaceutyczne „Polfa” S.A. } \\
\text { W } 1998 \text { roku 80\% akcji Polfy zakupił ten brytyjski koncern, } \\
\text { w } 1999 \text { posiadał już 88,7\%, a reszta należała ciagle do Skar- } \\
\text { bu Państwa i pracowników. Glaxo Wellcome ma swoje od- } \\
\text { działy w } 23 \text { krajach świata. W roku } 2000 \text { nastąpiła fuzja } \\
\text { koncernu z grupą SmithKline, zmieniając nazwę na Glaxo } \\
\text { SmithKline. }\end{array}$ \\
\hline \multicolumn{2}{|l|}{ 2) koncentracja drogą konsolidacji } \\
\hline $\begin{array}{l}\text { LECH Browary Wielkopolski S.A. } \\
\text { Browary Tyskie S.A. }\end{array}$ & $\begin{array}{l}\text { Fuzja obydwu browarów w } 1999 \text { roku doprowadziła do po- } \\
\text { wstania Kompanii Piwowarskiej z siedzibą w Poznaniu } \\
\text { i wspólnymi centrami dystrybucji. Już w } 1996 \text { roku dwóch } \\
\text { głównych akcjonariuszy LECHA - Euro Agro Centrum } \\
\text { i południowoafrykański koncern SAB Ltd zakupiło 52\% } \\
\text { udziałów w Browarach Tyskich, tworząc najsilniejszą grupę } \\
\text { piwowarską w kraju. }\end{array}$ \\
\hline
\end{tabular}

Źródło: opracowanie własne

Poprzez sprzedaż kontrolnych pakietów akcji niektóre duże przedsiębiorstwa przemysłowe Poznania weszły więc w struktury organizacyjne koncernów wielonarodowych, stając się podległymi im jednostkami organizacyjnymi, zachowującymi jednak pewien stopień samodzielności i odrębność prawną spółek, lecz tworzących razem wspólny organizm gospodarczy, poddany oddziaływaniu jednego ośrodka zarządzającego. Relacje zachodzące pomiędzy takim ośrodkiem zarządzającym a podległymi jednostkami mają charakter trwały i opierają się m.in. na kontroli zarządzania, prawach własności, zasobach finansowych, 


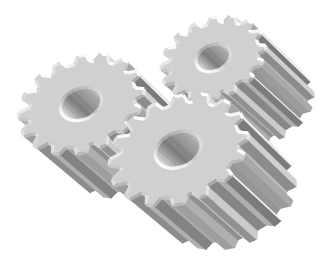

\section{ŚCIEŻKA ROZWOJU KONCERNU \\ AKTIEBOLAGET SKF \\ W POLSCE}

\section{SKF: ŚWIATOWY LIDER W PRODUKCJI LOŻYSK TOCZNYCH I USŁUGACH ZWIĄZANYCH Z TECHNIKĄ ŁOŻYSKOWĄ}

\footnotetext{
1. EKSPORT PRODUKTÓW NA RYNEK POLSKI
}

Obecność produktów SKF od 1923 roku. Dystrybucja produktów do 1990 roku odbywała się za pośrednictwem Szwedzkiego Biura Technicznego STB w Warszawie.

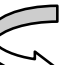
polskich fabryk łożysk tocznych wstrzymuje rozmowy

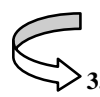
1991: SKF Polska Centrala Handlowo-Techniczna Sp. z o.o. w Warszawie 1992: SKF Polska Centrala Handlowo-Techniczna Sp. z o.o. Oddział Katowice

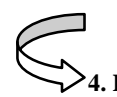

1993: rozmowy prywatyzacyjne z MPW zakończone tylko ustaleniami co do pakietu socjalnego załogi Fabryki Łożysk Tocznych

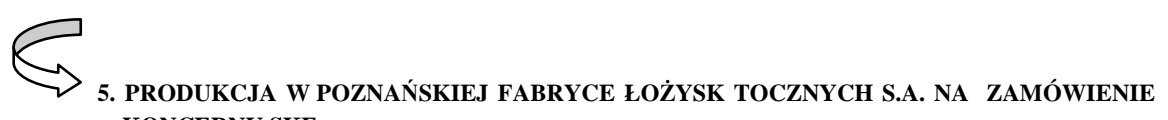
KONCERNU SKF

1993: nawiązanie współpracy FŁT S.A. z SKF Gőteborg na dostawy odkuwek łożysk baryłkowych 1994: produkcja wałeczków łożysk baryłkowych dla SKF Luton (Wielka Brytania) 1995: produkcja odkuwek łożyskowych dla SKF Malezja

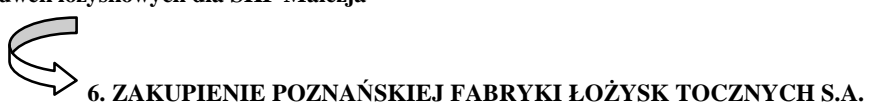

1995. 07.26: SKF zakupił 79\% akcji Fabryki Łożysk Tocznych S.A. w Poznaniu za 6 mln \$

1997. 10: przekazanie koncernowi SKF ostatniego $1 \%$ akcji fabryki należący do Skarbu Państwa, co oznacza zakończenie prywatyzacji fabryki. Akt ten nastąpił po wypełnieniu przez koncern zobowiązań z umów prywatyzacyjnych

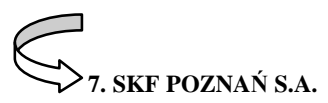

1997: włączenie się poznańskiej fabryki w struktury organizacyjne i produkcyjne SKF Group

2000: globalny koncern SKF Group zatrudnia ponad 38000 pracowników w 79 fabrykach w 70 krajach oraz w sieci dystrybucji 7000 przedstawicieli w 150 krajach świata

Ryc. 6. Ścieżka rozwoju AB SKF w Polsce

Źródło: opracowanie własne na podst. danych z przedsiębiorstwa 
komplementarności produkcji, usługach konsultingowych. Tego typu relacje, zachodzące między aktorami-uczestnikami gry ekonomicznej T. Stryjakiewicz (1999, s. 50) uznaje, na podstawie opracowania H.W. De Jong i J.G. Lambooy, za charakterystyczne dla identyfikacji sieci przemysłowych. Ponadto cytowany autor, powołując się na opracowania A. Lagendijka i G.A. van der Knaapa, zwraca uwagę, że bezpośrednie inwestycje zagraniczne są częścią procesu formowania się globalnych sieci przemysłowych. Można więc uznać, że poznańskie przedsiębiorstwa przemysłowe stały się elementem współczesnej, międzynarodowej przestrzeni przemysłowej, poprzez włączenie w sieci przemysłowe utworzone przez wielonarodowe koncerny.

Tworzenie sieci przemysłowych ma również aspekt przestrzenny, związany z ekspansją przedsiębiorstw wielonarodowych i globalizacją działalności gospodarczej. Również koncerny inicjujące koncentrację organizacyjną z dużymi przedsiębiorstwami przemysłowymi Poznania dokonują ekspansji przestrzennej w zdobywaniu rynku naszego kraju. Dla przedstawienia ekspansji terytorialnej koncernu wielonarodowego w Polsce można prześledzić ścieżkę rozwoju koncernu Aktiebolaget SKF Group (ryc. 6), skonstruowaną w myśl założeń modelu typowej ścieżki rozwoju przedsiębiorstwa wielonarodowego zaprezentowanego przez T. Stryjakiewicza (1999, s. 56). Koncern ten był inicjatorem koncentracji organizacyjnej z Fabryką Łożysk Tocznych S.A.

Analiza procesów koncentracji organizacyjnej zewnętrznej (integracji) oraz koncentracji organizacyjnej wewnętrznej w wyniku autonomizacji jednostek organizacyjnych, prowadzi do sformułowania pewnego spostrzeżenia: analizowane duże przedsiębiorstwa przemysłowe Poznania, włączając się w struktury organizacyjne międzynarodowych koncernów w wielu przypadkach podlegają dwupoziomowej autonomizacji (dywizjonalizacji). Z jednej strony stają się bowiem regionalnymi jednostkami organizacyjnymi ugrupowań gospodarczych (wielonarodowych koncernów) - i to jest jeden poziom, odzwierciedlający procesy koncentracji zewnętrznej. $\mathrm{Z}$ drugiej strony autonomizacji (fragmentaryzacji) ulegają ich wewnętrzne struktury organizacyjne, czego przejawem jest stopniowe usamodzielnianie się ich dotychczas integralnych jednostek organizacyjnych - i to jest drugi poziom autonomizacji, odzwierciedlający procesy związane z koncentracją wewnętrzną.

\section{Literatura}

Domański B., 1992, Postfordowski elastyczny model produkcji a jej przestrzenna organizacja, Biuletyn PAN KPZK 159, Warszawa, s. 49-75

Koziński J., 1996, Struktury organizacyjne ugrupowań gospodarczych, [w:] Struktury organizacyjne przedsiębiorstw i ich ugrupowań, red. R. Krupski, M. Przybyła, Wrocław-Warszawa-Kraków, s. $122-177$

Nizard G., 1991, tłum. pol. 1998, Les metamorphoses de l'enterprise. Pour une ecologie du management. Tłum. Z. Podlasiak, Metamorfozy przedsiębiorstwa. Zarzadzanie w zmiennym otoczeniu organizacji, Warszawa

Stryjakiewicz T., 1999, Adaptacja przestrzenna przemystu w Polsce w warunkach transformacji, Poznań

Wudarzewski W., 1996, Rodzaje struktur organizacyjnych przedsiębiorstw, [w:] Struktury organizacyjne przedsiębiorstw i ich ugrupowań, red. R. Krupski, M. Przybyła, Wrocław-WarszawaKraków, s. 51-90 